\title{
Effects of climate and landuse activities on water quality in the Yarra River catchment
}

\author{
$\underline{\text { S.K. Das }}^{\mathrm{a}}$, A.W.M. Ng ${ }^{\mathrm{a}}$, B.J.C. Perera ${ }^{\mathrm{a}}$, and S.K. Adhikary ${ }^{\mathrm{a}}$ \\ ${ }^{a}$ College of Engineering and Science, Victoria University, Melbourne 14428, Australia \\ Email: sushilkumar.das@live.vu.edu.au
}

\begin{abstract}
Since sediment and nutrient concentrations vary with landuses in different climatic conditions, it is critical in understanding the connection between different landuses activities and water quality, and developing appropriate management strategies for a catchment. The objective of this paper is to assess the effects of climate and landuse activities on nutrient and sediment loads at 5 selected water quality monitoring stations in the Yarra River catchment of Victoria, Australia for 1994-2008 periods. A data-based technique was applied to achieve the above objective using long-term in-stream water quality data and other readily available tools. The methodology addressed the issues of selecting water quality stations, catchment disaggregation, identification of major landuse types, analysis of pollutant concentrations and loads in different climatic conditions, and suitable data-based method (regression model LOADEST) to estimate pollutant loadings.
\end{abstract}

Climatic data were collected from the SILO climate database and the Bureau of Meteorology. Precipitation data from 16 stations and temperature data from 4 stations located in the Middle Yarra segment were collected for the period of 1980-2008. Daily streamflow and monthly water quality grab sample data of Total Suspended Solid (TSS), Total Nitrogen (TN) and Total Phosphorus (TP) were available for the 5 stations from Melbourne Water. ArcGIS 9.3 tool was used for catchment disaggregation and major landuse type identification using ASTER 30m global digital elevation model and landuse map (50m grid raster data collected from Australian Bureau of Agricultural and Resource Economics and Sciences). The water quality monitoring stations were selected based on data availability and dominant major landuse types (urban, agriculture and forest). The dominant landuse type in the tributary stations was either agriculture or urban where as in the main Yarra River stations; it was forest-agriculture mix type.

There was an abrupt drop in rainfall after 1996 known as millennium drought in the catchment, and the most extreme rainfall event occurs in that drought period. The study period was categorised into wet, dry and average years based on rainfall for water quality analysis purposes. Since the correlations between the concentrations of TSS, TN, TP, and streamflow (TSS: 0.57-0.72; TN: 0.50-0.57 and TP: 0.50-0.57 except station 5) were high and statistically significant $(\mathrm{p}<0.01)$, a regression method based model LOADEST was used to estimate constituent loads from the grab sample data. The LOADEST model is well documented, and is accepted as a valid means of calculating constituent load from a limited number of water quality data. The LOADEST model performed well in estimating TSS, TN and TP loads. Coefficients of determination $\left(\mathrm{R}^{2}\right)$ for the regression models in LOADEST were greater than $0.84,0.94$ and 0.88 for TSS, TN and TP respectively at all stations.

In general, TSS, TN and TP mean concentrations were higher in wet years than in the dry and average years, except at stations 2 and 3 where TN mean concentrations were higher in the average years. Also, TSS and TP mean concentrations were higher in the dry years than in the average years. This is due to the direct correlation of TSS and TP, and high runoff events. In addition, TSS, TN and TP mean concentrations were higher in the urban areas, and then in the agricultural areas. The four wet years $(1995,1996,2000$ and 2004) carried out on average $60 \%$ of TSS, $51 \%$ of TN and $53 \%$ of TP loadings in the monitoring stations. During the study period (1994-2008), the highest export rates of TSS, TN and TP were from urban areas, and the lowest export rates of TSS and TP were from forest areas, and TN from agricultural areas. Overall, water quality and constituent concentrations were influenced by rainfall events and landuse types.

Keywords: Pollutant concentrations and loads, Climate and landuse activities, Water quality, LOADEST, Yarra River catchment 
Das et al., Effects of climate and landuse activities on water quality in the Yarra River catchment

\section{INTRODUCTION}

Scarcity of water, deterioration of water quality and excessive sediments in rivers and creeks have become challenging issues for food supply, food security, human health and natural ecosystems. This is particularly the case with rapid changes in landuse and farming practices, and climate. In the last few decades, changes in landuse patterns caused by demographic, economic, political and/or cultural mutations have notable effects on water supply, water quality and soil erosion (Ingram et al., 1996). On the other hand, climate changes affect the hydrological cycle, thus modifying the transformation and transport characteristics of sediment and nutrients (Bouraoui et al., 2002). An increase in diffuse source pollutant loads, especially those from agricultural origins, is among the effects to be expected (Murdoch et al., 2000).

The Yarra River located in Victoria, Australia (Figure 1) has played a key role in the way Melbourne has developed and grown. Due to increases in population, recent landuse development in the catchment and inappropriate application of farming chemicals, the river water quality had degraded. The catchment is the largest generator of contaminants, both in terms of total load and load per unit area in the Port Phillip Bay region (Melbourne Water and EPA Victoria, 2009). The annual average rainfall has declined during the last decade within the Yarra River catchment compared to the long-term historical average (Muttil et al., 2009). Hence streamflow has become significantly lower than the long-term average in Yarra River catchment. The reduction in rainfall has had a positive effect on pollutant loads as less runoff from rural and urban catchments means fewer pollutants are washed into waterways and drains. However, the reduction in rainfall has also resulted in low dissolved oxygen levels in many smaller creeks.

A return to either higher average rainfall (signaling the end of a drought) or a move towards more frequent high rainfall events (storms) as is predicted as a result of climate change will result in increased loads being delivered to the waterways and bays (longer periods between runoff events and then high intensity events leading to concentrated pollutant runoff). There is an increasing body of scientific evidence that gives a collective picture of a warming world and other climate changes. This will have significant implications for the water resources systems. In recognition of this, Melbourne Water commissioned CSIRO to undertake a study on the implications of the impact of possible future climate change for the management of Melbourne's water, sewerage and drainage systems (Howe et al., 2005).

In general, assessment of the impacts of climate change on water quantity and quality will need to combine complex physics-based catchment models with the results of general circulation models (GCMs) (Bouraoui et al., 2002). However, these models require high expertise, high computational power and extensive data in all stages from model development to model calibration. Australian catchments are data-poor especially for water quality and land management practices data compared to Europe or America. Because of data-poor conditions, traditionally simpler water quality models such as Hossain et al. $(2012,2011)$ were used in the Australian catchments. Therefore, an alternative to the complex models is to use simple data-based techniques especially for management use where both time and data is limited (Worrall and Burt, 1999). Pollutant concentrations and estimated loads can be analyzed and correlated with different climatic conditions (dry, average or wet) and landuse types by data-based techniques.

There are different techniques used for load estimation, differing in complexity, accuracy and bias. Existing data-based methods for load estimation can be classified into three major classes: (i) averaging estimators, (ii) ratio estimators, and (iii) regression methods (Marsh and Waters, 2009). The averaging estimators are based on some form of averaging in concentration or flow data. The ratio estimators are based on the ratio of flow and concentration and often modified by a bias correction factor. The regression methods are based on fitting a relationship between flow and concentration for estimating a continuous trace of concentration. Based on the literature, Quilbe et al. (2006) suggested that: (i) averaging estimators are accurate only when concentration measurements are available for the entire flow range; (ii) the ratio estimators are less sensitive to river and pollutant characteristics than regression methods but requires more data to achieve the same level of precision; (iii) regression methods can give the best results for sediments and total phosphorus if streamflow and concentration data are strongly correlated for a wide range of streamflow values. Therefore, the regression method should be given priority if the correlation is high enough. Since the temporal variability of the relationship between concentration and streamflow can be very important, some authors proposed to define a regression equation as a function of time in order to take into account non-linearity as well as seasonal and long-term variability (Cohn et al., 1989).

The objective of this paper is to assess the effects of climate and landuse activities on nutrient and sediment loads at 5 selected water quality monitoring stations in the Yarra River catchment of Victoria, Australia for 1994-2008 periods. A data-based technique (regression method to estimate pollutant loads, and finding the effects of climate on the pollutant concentration/loads through statistical observation) was applied to achieve 
Das et al., Effects of climate and landuse activities on water quality in the Yarra River catchment

the above objective using long-term in-stream water quality data and other readily available tools such as ArcGIS. The methodology addressed the issues of selecting water quality stations, catchment disaggregation, identification of major landuse types, analysis of pollutant concentrations and loads in different climatic conditions, and suitable data-based method (regression model LOADEST) to estimate pollutant loadings.

\section{STUDY SITE DESCRIPTION}

The Yarra River catchment has an area of over 4,000 square kilometers. The Yarra River length from the head, at the Yarra Ranges National Park, to the end of its estuary, at Port Phillip Bay, is about $245 \mathrm{~km}$, with additional $1,800 \mathrm{~km}$ of named tributaries (EPA Victoria, 1999). About 21 percent of the catchment retains its natural vegetation, 57 percent is agricultural and 22 percent is urbanised. Three distinct segments, namely: Upper, Middle and Lower Yarra segments have been defined for

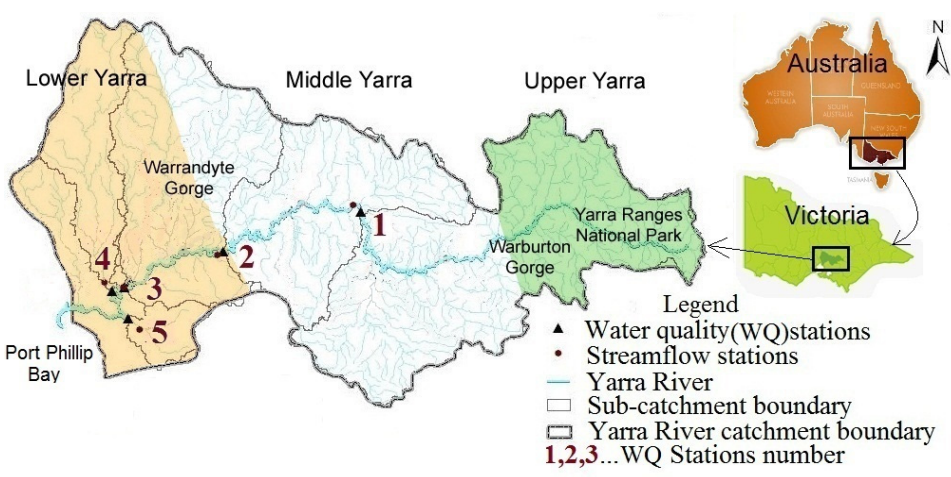

Figure 1. Yarra River catchment the Yarra River catchment, based on different landuse activities as shown in Figure 1. The Upper Yarra segment, from the Yarra Ranges National Park to the Warburton Gorge at Millgrove, consists of mainly dense and extensive forested area with minimum human population. The Middle Yarra segment, from the Warburton Gorge to Warrandyte Gorge, is mainly rural floodplains and valleys with limited urban development. The majority of the surrounding land is used for agricultural purposes. The Lower Yarra segment, downstream of Warrandyte, is mainly urbanised floodplains, and has the poorest water quality. The annual rainfall of the Yarra River catchment varies from approximately 1,600 $\mathrm{mm}$ in the Upper Yarra area to about $600 \mathrm{~mm}$ in the Lower Yarra region ( $\mathrm{Ng}$ et al., 2006). Low flows occur from November to June, whereas high flows occur during other times of the year.

\section{MATERIALS AND METHODS}

\subsection{Data Collection and Preliminary Analysis}

Climatic data were collected from the SILO climate database (http://www.longpaddock.qld.gov.au/silo/; accessed $10^{\text {th }}$ September 2010) and Bureau of Meteorology, Australia. Precipitation data from 16 stations and temperature data from 4 stations located around the Middle Yarra segment were collected for the period of 1980-2008. Figure 2 shows that there is an abrupt drop in annual average rainfall (from $1140 \mathrm{~mm}$ to $922 \mathrm{~mm}$ ) from 1997 onwards indicating one of the most severe drought events (known as millennium drought) in the catchment. The average annual maximum temperature increased about $0.53^{\circ} \mathrm{C}$, and minimum temperature decreased about $0.30^{\circ} \mathrm{C}$ during this drought period.

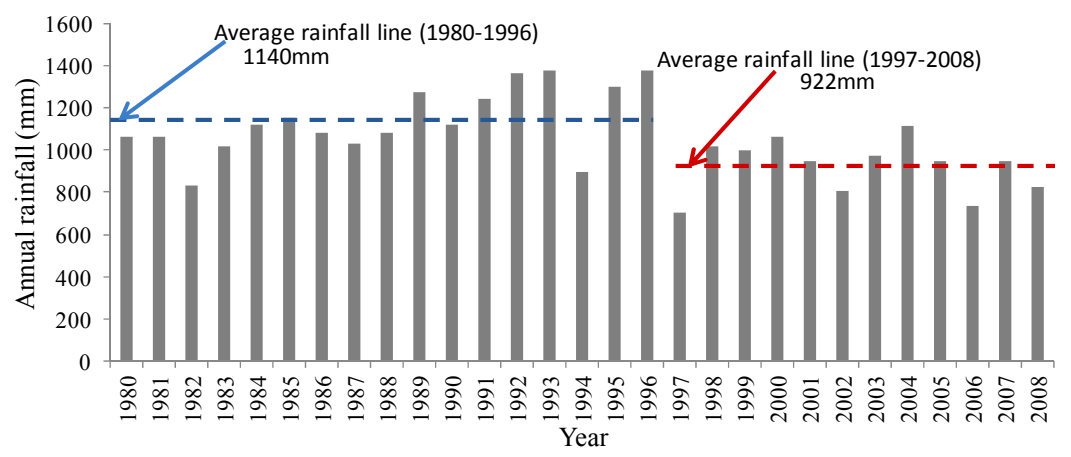

Figure 2. Annual rainfall in the Yarra River catchment

The rainfall analysis also showed that high intensity rainfall $(40 \mathrm{~mm}$ or above) occurred regularly in the drought period, and the most extreme rainfall event $(119 \mathrm{~mm})$ also occurred in that drought period as shown in Figure 3 with streamflow data from a middle Yarra station. The mean annual rainfall in the Yarra River catchment during the study period $1994-2008$ is $1049 \mathrm{~mm}$. Based on the mean annual rainfall, the study period is categorized into dry (1997, 2002, 2006 and 2008: mean annual rainfall 825mm), wet (1995, 1996, 
Das et al., Effects of climate and landuse activities on water quality in the Yarra River catchment

2000, 2004: mean annual rainfall 1311mm), and average (1994, 1998, 1999, 2001, 2003, 2005 and 2007: mean annual rainfall $1027 \mathrm{~mm}$ ) years for water quality analysis purposes.

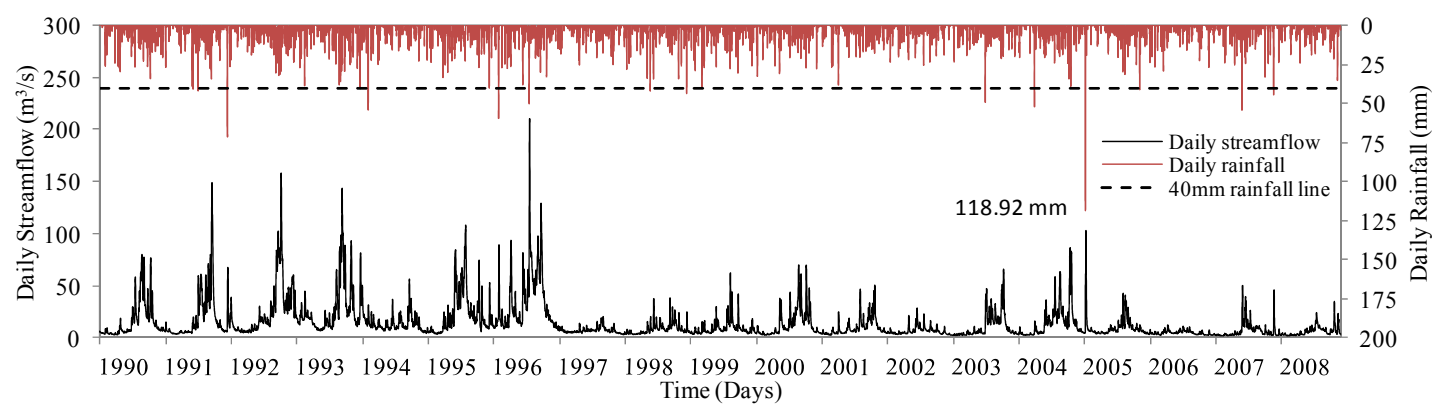

Figure 3. Daily rainfall and streamflow at Warrandyte (station 2)

The major water quality monitoring program in the Yarra River catchment is the Melbourne Water's monitoring network at 33 stations on monthly basis along the Yarra River and its tributaries. Among 33 stations, 5 stations were selected of which 3 stations are on the main stream of the Yarra River as shown in Figure 1 and Table 1. These 5 stations were selected based on data characteristics (data availability, censored or missing) and major landuse types. Available water quality grab sample data of Total Suspended Solids (TSS), Total Nitrogen (TN) and Total Phosphorus (TP) data were collected for these stations from Melbourne Water for the period of 1994 to 2008. In 1994 to 1997 period, data were available almost on weekly basis (except station 1), and afterwards on monthly basis. In the Yarra River catchment, phosphorus is the key pollutant in the waterways whereas in Port Phillip Bay, nitrogen is the key nutrient affecting algal growth and need to be managed to maintain the health of the bay (Melbourne Water and EPA Victoria, 2009). The corresponding daily streamflow data were collected from nearby 5 streamflow stations of Melbourne Water. Table 1 shows that the study period is very dry compared to the whole period of record although 1995 and 1996 were very wet years.

Table 1. Monitoring stations and streamflow statistics (station number corresponds to Figure 1)

\begin{tabular}{|c|c|c|c|c|c|c|c|c|c|}
\hline \multirow{3}{*}{$\begin{array}{l}\text { Station } \\
\text { Number }\end{array}$} & \multirow[t]{3}{*}{ Water quality stations } & \multirow[t]{3}{*}{ Easting } & \multirow[t]{3}{*}{ Northing } & \multirow{3}{*}{$\begin{array}{c}\text { No. of } \\
\text { water quality } \\
\text { observations }\end{array}$} & \multirow{3}{*}{$\begin{array}{l}\text { Period of } \\
\text { streamflow } \\
\text { record }\end{array}$} & \multicolumn{4}{|c|}{ Daily streamflow $\left(\mathrm{m}^{3} / \mathrm{s}\right)$} \\
\hline & & & & & & \multicolumn{3}{|c|}{ Study period 1994-2008 } & \multirow{2}{*}{$\frac{\text { Period of record }}{\text { Mean }}$} \\
\hline & & & & & & Min. & Mean & Max. & \\
\hline 1 & Yarra River at Healesville & 367012 & 5828984 & 185 & $1980-2008$ & 0.962 & 8.84 & 234.13 & 10.77 \\
\hline 2 & Yarra River at Warrandyte & 343212 & 5821984 & 306 & $1970-2008$ & 1.285 & 9.88 & 209.67 & 13.01 \\
\hline 3 & Yarra River at Kew & 326212 & 5815784 & 342 & $1975-2008$ & 0.886 & 11.43 & 218.57 & 13.98 \\
\hline 4 & Merri Creek at Yarra Bend & 324192 & 5815224 & 279 & $1975-2008$ & 0.040 & 0.84 & 106.13 & 1.13 \\
\hline 5 & Gardiners Creek at Hawthorn & 326912 & 5810384 & 306 & $1978-2008$ & 0.001 & 0.62 & 48.28 & 0.76 \\
\hline
\end{tabular}

A sub-catchment map defining drainage area for each Table 2. Percentage of major landuses in the water quality sampling station was generated from ASTER $30 \mathrm{~m}$ global digital elevation model Station Landuse type Drainage (http://asterweb.jpl.nasa.gov/gdem-wist.asp; accessed $4^{\text {th }}$ Number $\overline{\text { Forest Agriculture Urban Others Area }}$ November 2010) using ArcGIS 9.3 tools. A land cover map (50m grid raster data collected from Australian Bureau of Agricultural and Resource Economics and Sciences-ABARES, http://adl.brs.gov.au/landuse; accessed $7^{\text {th }}$ June 2010) was overlaid and the proportions of major landuses in each sub-catchment were calculated as

\begin{tabular}{cccccc} 
& $\begin{array}{c}\text { Forest } \\
(\%)\end{array}$ & $\begin{array}{c}\text { Agriculture } \\
(\%)\end{array}$ & $\begin{array}{c}\text { Urban } \\
(\%)\end{array}$ & $\begin{array}{c}\text { Others } \\
(\%)\end{array}$ & $\left(\mathrm{km}^{2}\right)$ \\
\hline 1 & $\mathbf{5 0}$ & 44 & 6 & 0 & 1566 \\
2 & $\mathbf{4 6}$ & 43 & 10 & 1 & 2354 \\
3 & 38 & $\mathbf{4 3}$ & 18 & 1 & 3323 \\
4 & 2 & $\mathbf{6 7}$ & 31 & 0 & 392 \\
5 & 0 & 0 & $\mathbf{1 0 0}$ & 0 & 107 \\
\hline
\end{tabular}
presented in Table 2. The dominant landuse type in the tributary stations was either agriculture (station 4) or urban (station 5) where as it was forest-agriculture mix type in the main Yarra River stations.

\subsection{Estimation of Pollutant Loads and Yields}

First, the correlations between daily streamflow and concentrations of TN, TP and TSS were determined at all water quality stations. Since the correlations between the concentrations of TSS, TN, TP, and streamflow (TSS: $0.57-0.72$; TN: $0.50-0.57$ and TP: $0.50-0.57$ except station 5) were high and statistically significant $(\mathrm{p}<0.01)$, a regression method is selected to estimate the pollutant loadings. Then the regression method based model LOADEST (Runkel et al., 2004) was used to estimate constituent loads from the grab sample data. The LOADEST model is well accepted for calculating constituent load from a limited number of water quality data (Jha et al., 2007). The LOADEST model evaluates the relationships between pollutant loads, and streamflow and time variables to consider time trend and seasonal trend based on eleven predefined models 
Das et al., Effects of climate and landuse activities on water quality in the Yarra River catchment

or a user-defined model. The users can select a model manually or automatically based on lowest value of Akaike's Information Criterion (AIC) (Akaike, 1974). For example, the seven-parameter model;

$\ln (\mathrm{L})=\mathrm{a}_{0}+\mathrm{a}_{1} \ln \mathrm{Q}+\mathrm{a}_{2} \ln \mathrm{Q}^{2}+\mathrm{a}_{3} \sin (2 \pi \mathrm{dtime})+\mathrm{a}_{4} \cos (2 \pi \mathrm{dtime})+\mathrm{a}_{5} \mathrm{dtime}+\mathrm{a}_{6} \mathrm{dtime}^{2}$

where $\mathrm{L}=$ pollutant load in $\mathrm{kg} /$ day; $\mathrm{a}_{0}=$ regression constant; $\mathrm{a}_{1}, \mathrm{a}_{2}, \mathrm{a}_{3}, \mathrm{a}_{4}, \mathrm{a}_{5}, \mathrm{a}_{6}=$ regression coefficients; $\mathrm{Q}=$ daily mean streamflow in $\mathrm{ft}^{3} / \mathrm{s}$; dtime $=$ time parameter in decimal years. The best model was selected automatically in LOADEST based on AIC at each station. Adjusted maximum likelihood estimation and calibration option was selected in LOADEST as residuals approximated a normal distribution, and sometimes contained censored data. Figure 4 shows plotting of residuals against explanatory (streamflow and time) and predicted variables (estimated load) at station 2 as a typical case for $\mathrm{TN}$; they were reasonably homoscedastic. Similarly, the goodness of fit in the estimation was also tested by normal probability plot of the residuals, and found to be normally distributed as shown in Figure 4d.
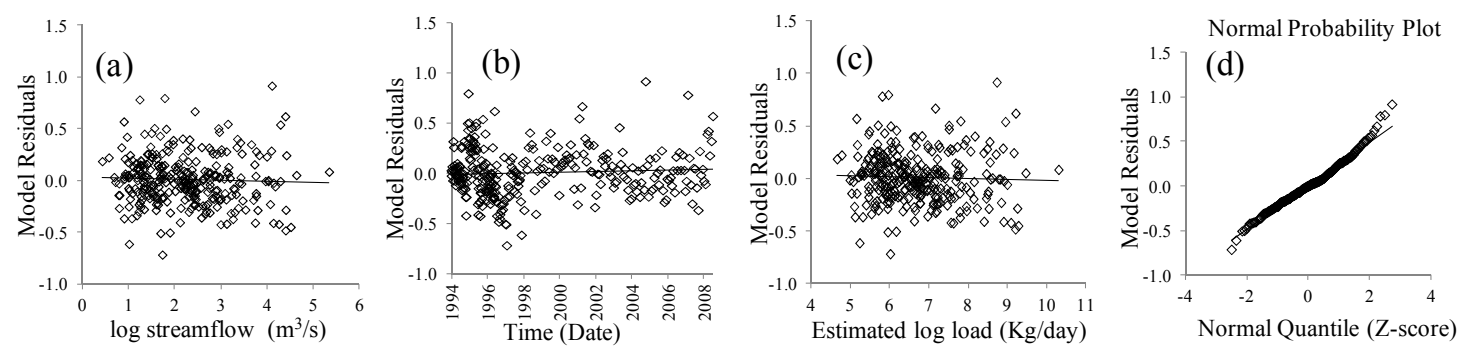

Figure 4. Model residuals against (a) streamflow (b) time and (c) estimated load, and (d) normal probability plot for TN at Warrandyte (station 2)

The LOADEST model performed well in estimating TSS, TN and TP loads. The coefficients of determination $\left(\mathrm{R}^{2}\right)$ for the regression models in LOADEST were greater than $0.84,0.94$ and 0.88 for TSS, TN and TP respectively at all stations. The $\mathrm{R}^{2}$ value indicates the "variability explained" by the models for logarithm of loads. Figure 5 shows a typical case of comparison between observed and estimated TSS, TN and TP loadings (back-transformed to data scale) only on grab sampling days at Warrandyte station.
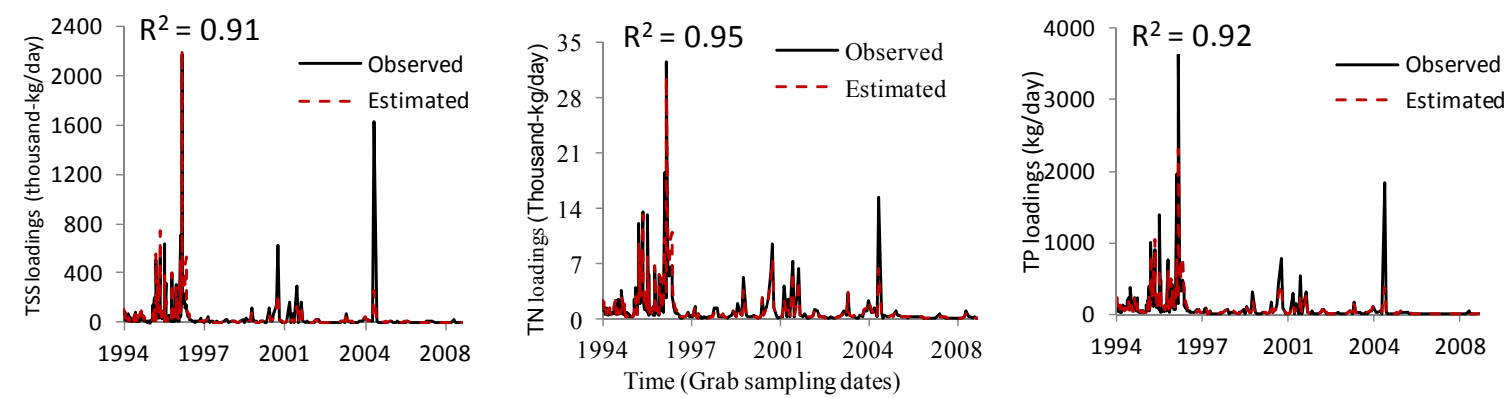

Figure 5. Observed versus estimated TSS, TN and TP loadings at Warrandyte (station 2)

Observed loads were calculated on the particular grab sampling days by multiplying observed daily streamflow by observed pollutant concentration, and compared with estimated loads on those days. TN, TP and TSS yields were calculated by dividing their annual loads by the corresponding station's drainage area.

\section{RESULTS AND DISCUSSION}

\subsection{Pollutant Concentrations}

The study period (1994-2008) included both very wet and extreme drought event in the history of the catchment which affected the pollutant generation processes (Figure 2). Years 1996, 2003 and 1997 were considered as representative of wet, average and dry year respectively for analysis purposes. Statistical analysis (maximum, minimum, and mean) of pollutant concentrations is shown in Table 3. In general, TSS, TN and TP mean concentrations were higher in wet years than in the dry and average years, except at stations 2 and 3 where TN mean concentrations were higher in the average years. Also, TSS and TP mean concentrations were higher in the dry years than in the average years. This is due to the direct correlation of TSS and TP, and high runoff events. In addition, TSS, TN and TP mean concentrations were higher in the urban areas, and then in the agricultural areas. 
Das et al., Effects of climate and landuse activities on water quality in the Yarra River catchment

\begin{tabular}{|c|c|c|c|c|c|c|c|c|c|c|c|c|c|}
\hline \multirow{2}{*}{$\begin{array}{l}\text { Station } \\
\text { Number }\end{array}$} & \multirow{2}{*}{$\begin{array}{l}\text { 䔍 } \\
\text { 冚 } \\
\text { م }\end{array}$} & \multicolumn{3}{|c|}{$\begin{array}{c}\text { Wet year }(1996) \\
\text { concentrations }(\mathrm{mg} / \mathrm{L})\end{array}$} & \multicolumn{3}{|c|}{$\begin{array}{l}\text { Average year }(2003) \\
\text { concentrations }(\mathrm{mg} / \mathrm{L})\end{array}$} & \multicolumn{3}{|c|}{$\begin{array}{c}\text { Dry year (1997) } \\
\text { concentrations }(\mathrm{mg} / \mathrm{L})\end{array}$} & \multicolumn{3}{|c|}{$\begin{array}{c}\text { Study period }(1994-2009) \\
\text { concentrations }(\mathrm{mg} / \mathrm{L})\end{array}$} \\
\hline & & Min. & Mean & Max. & Min. & Mean & Max. & Min. & Mean & Max. & Min. & Mean & Max. \\
\hline \multirow{3}{*}{1} & TSS & 11 & 29 & 93 & 6 & 10 & 13 & 10 & 18 & 36 & 1 & 16 & 230 \\
\hline & $\mathrm{TN}$ & 0.60 & 0.86 & 1.31 & 0.55 & 0.78 & 1.30 & 0.49 & 0.68 & 1.10 & 0.19 & 0.80 & 2.29 \\
\hline & TP & 0.03 & 0.05 & 0.10 & 0.02 & 0.03 & 0.04 & 0.02 & 0.04 & 0.07 & 0.003 & 0.04 & 0.30 \\
\hline \multirow{4}{*}{2} & TSS & 7 & 28 & 120 & 4 & 8 & 23 & 5 & 13 & 36 & 1 & 20 & 310 \\
\hline & $\mathrm{TN}$ & 0.62 & 0.97 & 2.63 & 0.79 & 1.13 & 1.93 & 0.40 & 0.88 & 1.23 & 0.40 & 1.04 & 2.93 \\
\hline & $\mathrm{TP}$ & 0.03 & 0.07 & 0.28 & 0.04 & 0.06 & 0.08 & 0.04 & 0.07 & 0.15 & 0.009 & 0.07 & 0.35 \\
\hline & TSS & 14 & 49 & 210 & 16 & 31 & 52 & 9 & 34 & 200 & 4 & 37 & 280 \\
\hline \multirow[t]{3}{*}{3} & $\mathrm{TN}$ & 0.69 & 1.18 & 3.07 & 0.70 & 1.48 & 2.31 & 0.48 & 1.04 & 1.79 & 0.36 & 1.16 & 3.07 \\
\hline & $\mathrm{TP}$ & 0.04 & 0.10 & 0.35 & 0.05 & 0.09 & 0.15 & 0.05 & 0.08 & 0.19 & 0.024 & 0.09 & 0.36 \\
\hline & TSS & 2 & 24 & 100 & 1 & 12 & 33 & 1 & 9 & 78 & 1 & 14 & 100 \\
\hline \multirow[t]{3}{*}{4} & $\mathrm{TN}$ & 1.14 & 2.44 & 5.15 & 0.81 & 1.52 & 3.46 & 1.05 & 1.51 & 2.32 & 0.20 & 1.63 & 5.15 \\
\hline & $\mathrm{TP}$ & 0.07 & 0.20 & 0.46 & 0.06 & 0.13 & 0.23 & 0.07 & 0.14 & 0.41 & 0.028 & 0.14 & 0.57 \\
\hline & TSS & 8 & 43 & 200 & 4 & 14 & 39 & 4 & 31 & 160 & 1 & 49 & 1200 \\
\hline \multirow[t]{2}{*}{5} & $\mathrm{TN}$ & 1.10 & 1.99 & 4.83 & 1.00 & 1.69 & 2.85 & 1.11 & 1.72 & 4.22 & 0.18 & 2.00 & 13.26 \\
\hline & $\mathrm{TP}$ & 0.05 & 0.13 & 0.30 & 0.05 & 0.11 & 0.19 & 0.05 & 0.11 & 0.37 & 0.01 & 0.15 & 2.60 \\
\hline
\end{tabular}

\subsection{Estimated Annual Loads and Yields}

In general, TSS, TN and TP annual loads in different climatic years (wet, average and dry) or during the study period (1994-2008) increased from upstream to downstream in the main stream stations as shown in Figure 6. However, annual load at the station 2 was not higher than that of the station 1 during the dry year especially for TSS (Figure 6). This may be because of the Yering Gorge pumping station located in upstream of the station 2 which withdraws significant amount of water during dry years, and that pumped out water was not considered during the load estimation. The four wet years (1995, 1996, 2000 and 2004) carried out on average $60 \%$ of TSS, $51 \%$ of TN and $53 \%$ of TP loadings in the monitoring stations.

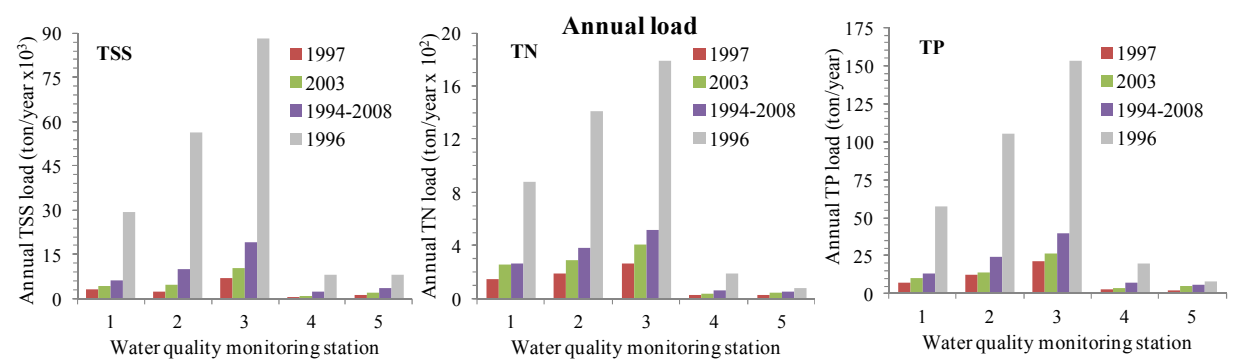

Figure 6. Annual loads of TSS, TN and TP in different climatic years of the Yarra River catchment

Figure 7 shows that during the study period (1994-2008) and wet year (1996), the highest yields/export rates of TSS, TN and TP were from urban areas, and the lowest export rates of TSS and TP were from forest areas, and TN from agricultural areas. Similarly, during the dry (1997) and average (2003) year, the highest export rates of TSS, TN and TP were from urban areas, and the lowest export rates of TP were from forest areas. However, the lowest export rates of TSS and TN from were from agricultural areas.
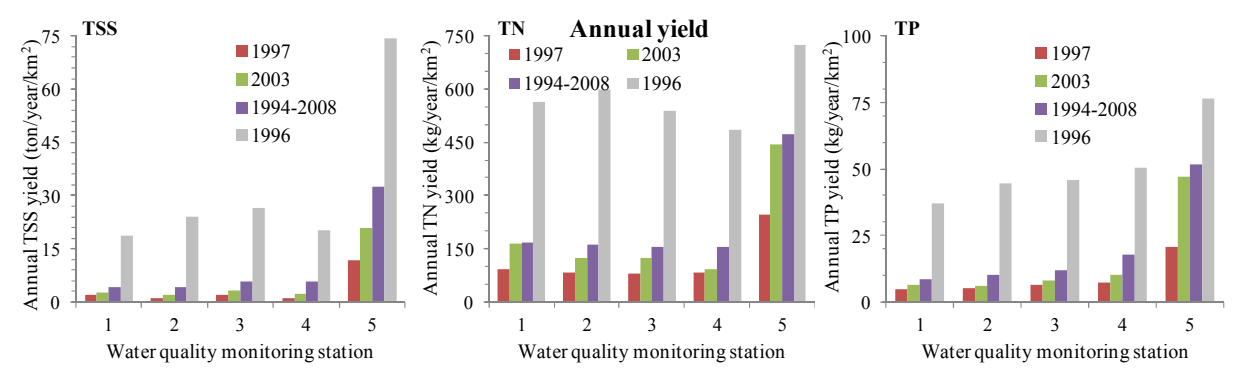

Figure 7. Annual yields of TSS, TN and TP in different climatic years of the Yarra River catchment

\section{CONCLUSIONS}

Effects of climate and landuse activities on nutrient (TN, TP) and sediment (TSS) loads have been assessed in the Yarra River catchment of Victoria, Australia. A simple data-based technique was applied using long- 
Das et al., Effects of climate and landuse activities on water quality in the Yarra River catchment

term in-stream water quality data and other readily available tools rather than using complex catchment models and GCMs. The methodology is simple to apply, and can be used as a first step for management purposes where limited time and data available. The study period (1994-2008) included both very wet and extreme drought event in the history of the catchment which affected the pollutant generation processes. In general, TSS, TN and TP mean concentrations were higher in wet years than in the dry and average years. In addition, TSS, TN and TP mean concentrations were higher in the urban areas, and then in the agricultural areas. The LOADEST model performed well in estimating TSS, TN and TP loads $\left(\mathrm{R}^{2}>0.84\right)$ at all stations from monthly grab sample data. The four wet years (1995, 1996, 2000 and 2004) carried out on average 60\% of TSS, $51 \%$ of TN and 53\% of TP loadings in the monitoring stations. During the study period, the highest export rates of TSS, TN and TP were from urban areas, and the lowest export rates of TSS and TP were from forest areas, and TN from agricultural areas. Overall, water quality and constituent concentrations were influenced by rainfall events and landuse types.

\section{ACKNOWLEDGMENTS}

The authors wish to thank Melbourne Water, ABARES, SILO climate database, Bureau of Meteorology, U.S. Geological Survey and NASA-Japan government for providing data and tools for this study.

\section{REFERENCES}

Akaike, H. (1974). A new look at the statistical model identification. IEEE Transactions on Automatic Control, 19(6), 716-723.

Bouraoui, F., Galbiati, L., and Bidoglio, G. (2002). Climate change impacts on nutrient loads in the Yorkshire Ouse catchment (UK). Hydrology and Earth System Sciences Discussions, 6(2), 197-209.

Cohn, T.A., Delong, L.L., Gilroy, E.J., Hirsch, R.M., and Wells, D.K. (1989). Estimating constituent loads. Water Resources Research, 25(5), 937-942.

EPA Victoria (1999). Policy impact assessment: protecting the environmental health of Yarra catchment waterways, Report No. 654, Melbourne, Australia.

Hossain, I., Imteaz, M.A., and Hossain, M.I. (2011). Application of build-up and wash-off models for an East-Australian catchment. Journal of World Academy of Science, Engineering and Technology, 75(162), 941-746.

Hossain, I., Imteaz, M.A., and Hossain, M.I. (2012). Application of catchment water quality model for an East-Australian catchment. International Journal of Global Environmental Issues, 12(2-4), 242-255.

Howe, C., Jones, R.N., Maheepala, S., and Rhodes, B. (2005). Melbourne Water climate change study Implications of potential climate change for Melbourne's water resources, CMIT-2005-106, CSIRO and Melbourne Water, Melbourne, Australia.

Ingram, J., Lee, J., and Valentin, C. (1996). The GCTE soil erosion network: A multidisciplinary research program. Journal of Soil and Water Conservation, 51(5), 377-380.

Jha, M.K., Gassman, P.W., and Arnold, J.G. (2007). Water quality modeling for the Raccoon River watershed using SWAT. Transactions of the ASABE, 50(2), 479-493.

Marsh, N., and Waters, D. (2009). Comparison of load estimation methods and their associated error, In R.S. Anderssen, R.D. Braddock and L.T.H. Newham (eds), The 18th World IMACS Congress and MODSIM09 International Congress on Modelling and Simulation, Cairns, July 13-17, pp.3322-3328.

Melbourne Water and EPA Victoria (2009). Better Bays and Waterways - A Water Quality Improvement Plan for the Port Phillip and Westernport Region, Melbourne, Australia.

Murdoch, P.S., Baron, J.S., and Miller, T.L. (2000). Potential effects of climate change on surface-water quality in North America. Journal of the American Water Resources Association, 36(2), 347-366.

Muttil, N., Barua, S., Ng, A.W.M., and Perera, B.J.C. (2009). Spatio-temporal analysis to detect climate changes within the Yarra River catchment, In Ozwater '09: Australia's National Water Conference and Exhibition, Melbourne, Australia.

Ng, A.W.M., Perera, B.J.C., and Tran, D.H. (2006). Improvement of river water quality through a seasonal effluent discharge program (SEDP). Water, Air, and Soil Pollution, 176(1), 113-137.

Quilbe, R., Rousseau, A.N., Duchemin, M., Poulin, A., Gangbazo, G., and Villeneuve, J.P. (2006). Selecting a calculation method to estimate sediment and nutrient loads in streams: Application to the Beaurivage River (Quebec, Canada). Journal of Hydrology, 326(1-4), 295-310.

Runkel, R.L. Crawford, C.G., and Cohn, T.A. (2004). Load Estimator (LOADEST): A FORTRAN program for estimating constituent loads in streams and rivers. In: Techniques and Methods Book 4, Chapter 5, pp.69. US Department of the Interior, US Geological Survey, Reston, Virginia.

Worrall, F., and Burt, T.P. (1999). The impact of land-use change on water quality at the catchment scale: the use of export coefficient and structural models. Journal of Hydrology, 221(1-2), 75-90. 